\title{
The Political Import of
}

Deconstruction-Derrida's Limits?:

A Forum on Jacques Derrida's

Specters of Marx after 25 Years,

Part I

\author{
Maja Zehfuss* \\ Antonio Y. Vázquez-Arroyo** \\ Dan Bulley ${ }^{* * *}$ \\ Bal Sokhi-Bulley ${ }^{* * *}$
}

\begin{abstract}
Jacques Derrida delivered the basis of The Specters of Marx: The State of the Debt, the Work of Mourning, \& the New International as a plenary address at the conference 'Whither Marxism?' hosted by the University of California, Riverside, in 1993. The longer book version was published in French the same year and appeared in English and Portuguese the following year. In the decade after the publication of Specters, Derrida's analyses provoked a large critical literature and invited both consternation and celebration by figures such as Antonio Negri, Wendy Brown and Frederic Jameson. This forum seeks to stimulate new reflections on Derrida, deconstruction and Specters of Marx by considering how the futures past announced by the book have fared after an eventful quarter century. Maja Zehfuss, Antonio Vázquez-Arroyo and Dan Bulley and Bal Sokhi-Bulley offer sharp, occasionally exasperated, meditations on the political import of deconstruction and the limits of Derrida's diagnoses in Specters of Marx but also identify possible paths forward for a global politics taking inspiration in Derrida's work of the 1990s.
\end{abstract}

Keywords: Derrida, Jacques; deconstruction; global politics; immigration; citizenship; ethics; friendship.

\footnotetext{
* University of Manchester, Manchester, UK; maja.zehfuss@manchester.ac.uk. ORCID iD 0000-0003-4651-4229.

** Rutgers University-Newark, Newark, USA; a.vazquez@rutgers.edu. ORCID iD 0000-0003-1817-6381.

*** Oxford Brookes University, Oxford, UK; dbulley@brookes.ac.uk. ORCID iD 0000-0003-1624-7617.

**** University of Sussex, Brighton, UK; b.sokhi-bulley@sussex.ac.uk. ORCID iD 0000-0003-2143-8098.
} 


\section{Specters at 25: The State of the World and the Question of Home}

Maja Zehfuss

How to respond to Specters of Marx 25 years on? ${ }^{1}$ What is it even about? On my reading, and without any claim to comprehensiveness, Spectres reflects on temporality through Shakespeare, appreciates the continued significance of Marxist thought, critiques The End of History (Fukuyama 1992) or rather the triumphalist Fukuyama-hype, diagnoses the state of the world, riffs on the question of critique and, most mysteriously, framing everything, meditates on how to live. The editors, of course, tell us confidently that Spectres addresses the 'connection between the death of communism and the fate of Marxism' (Magnus and Cullenberg 1994: xi). Since I do not have the expertise or inclination, I cannot respond to Spectres as a 'book on Marx,' as Derrida himself has put it (Peeters 2013: 463), by assessing its past contribution, celebrating its significance in the present and projecting its continued influence in the future in the manner of an anniversary.

Nor can I tease out the book's influence on my own work. To the best of my knowledge, I have never explicitly drawn on Specters. My failure to do so might be seen as counterintuitive inasmuch as the question of memory or, one might say, the ways in which the past haunts the present (Zehfuss 2007, 2015) is something that figures prominently in my work and was even central to it for some time. This work is inspired by and in conversation with Derrida, and yet it was not the idea of 'a hauntology' (Derrida 1994: 10), introduced in Specters, that interested me, but rather the unsettling of categories and their boundaries effected in Derrida's work that enables me to trace the complexities and contradictions in how truth, time, subjectivity, emotion and ethics are conceptualised. In turn, this allows me to show that political questions must be responded to beyond the apparent safety offered by knowledge.

Perhaps this is fortuitous, as the implied inscription of linearity in such performed encounters with seminal books would sit uneasily with Derrida's thinking, although no doubt he would have found a way to play on the genre, tracing the spectre of Specters perhaps. Instead, I simply draw out two themes, the state of the world and the question of home.

\section{The State of the World}

Re-reading Specters of Marx in 2019 reveals both how little has changed over the last 25 years and how much the same is different. I cannot read Specters now without experiencing a tension, a prominent silence, something that - I admit - had not affected me before. While attentive to structural global inequality (Derrida 1994: 85) and cognisant of the problems of the 'new international order' (Derrida 1994: 80-81) emerging in the 1990s, the book nevertheless makes the politics and philosophy in and of the North the undisputed centre of what is at stake in and for the world. 
Derrida forcefully rejects the triumphalism of Francis Fukuyama's 'end of history' thesis, asserting and illustrating instead the continuing relevance of Marx, the ghost that now haunts us. At the time, this was bold, even jarring, something difficult to recall now as Marx's pivotal contribution has become more apparent than ever. While the ideological struggle between the communist and liberal ideals on either side of the superpower confrontation, and therefore its end, had global reach and impact, there is something peculiar about the way in which Specters does not query the exclusive focus on white men and their interpreters. Put differently, the North as at the centre of the struggle over the meaning of the past and the future of politics does not seem to be in doubt. The book does not trace how the proposition of an 'end of history' already captures a Eurocentrism that is inattentive to the ways in which its cosmology relies on a universalization of identity that renders 'beyond Europe' invisible. It thus excludes from view the power those at the centre of this cosmology exert, knowingly or not, over those who are assigned to its margins or erased altogether.

This apparent blind spot is arguably surprising in the context of Derrida's work more broadly. After all, Of Grammatology asserts, on the first page, how what Derrida calls logocentrism is 'the most original and powerful ethnocentrism' (Derrida 1998: 3; see also Glendinning 2011: 36-39). That is, Derrida's critique of Western philosophy draws attention to the power involved in its operation from the start. One might even say, if that is possible, that this is what it is about, albeit as a conceptual problem.

Derrida proposes an openness towards the future, 'beyond the closure of knowledge' (Derrida 1998: 4). This future, he says, 'can only be anticipated in the form of an absolute danger' (Derrida 1998: 5). Although, of course, the whole point about the future is that it cannot be known, as if it were it would cease being the future, Simon Glendinning's (2011: 39) assertion that undoubtedly 'this future would be one in which the classic (Western) understanding of the history of the world and the significance of human life no longer dominates' seems pertinent. Yet, despite calling up a New International in Specters, what is now often called the Global South appears visible at best as an object of the contemporary geopolitical configuration. This absence is perhaps particularly baffling as Spectres is dedicated to Chris Hani, who - while assassinated for being a communist - is of the world made invisible in the book.

The Other Heading (Derrida 1992), containing some of Derrida's work of roughly the same time, openly embraces the significance of the idea of Europe, articulates a desire for 'Europe' in this sense. And yet this text, more than Specters, acknowledges the particularity and privilege of Europe, examining the question of who 'will draw up its borders' and, crucially, its implication in the 'worst violences' being unleashed 'in the name of identity', among them xenophobia and racism (Derrida 1992: 5-6). The problem that Europe or, in Specters, democracy relies on exclusion, that they are historically and therefore conceptually implicated in racism, seems to disappear into the background in the latter.

In the third part of Specters, 'wears and tears (tableau of an ageless world), Derrida takes his cue from the twin observations that 'the time is out of joint' and that the 'world is going badly' (Derrida 1994: 76). He lambasts the 'imperturbable thoughtlessness that con- 
sists in singing the triumph of capitalism or of economic and political liberalism' (Derrida 1994: 78). Some of the analysis strongly resonates with our predicament today, although I am not sure whether this means Derrida was prescient or merely that nothing much has changed. His observation that 'public space' in Western democracies is 'profoundly upset by techno-tele-media apparatuses and by new rhythms of information and communication' (Derrida 1994: 79) rings true today and might have been novel at the time. This was before the introduction of smartphones, after all, and a whole decade before Facebook entered our lives. Derrida (1994: 79) points out that this 'transformation does not affect only the facts but the concept of such "facts," again articulating something widely accepted now, but perhaps not so obvious then.

Yet when Derrida (1994: 81-84) diagnoses the ten 'plagues' of the 'new world order', these seem a collection of grievances that might be listed, perhaps with the exception of the invocation of ontopology (about which more below), by any leftist observer. Worse, he displays, as he frequently does, his faith in international institutions, to which he attributes a 'fortunate perfectibility', despite acknowledging their historical rootedness in European philosophical concepts (Derrida 1994: 83), that is, in the very philosophy he denounces as logocentric. To be fair, he notes the limitations, indeed hypocrisy, of the discourse of human rights (Derrida 1994: 85), but he seems nevertheless determined to embrace their institutional expression.

Elsewhere, Derrida (1992: 7) acknowledges his own identity as 'a sort of over-acculturated, over-colonized European hybrid.' Across his more overtly political writings, he appears forever torn between the promise of the institutions of the West and an awareness of their inextricable implication in the very violence they claim to be designed against. Put differently, Derrida's analysis of politics often, and certainly in Spectres, appears to be infused by a hopeful internationalism that too quickly embraces certain international institutions. In sum, Derrida is at his most brilliant when he draws out the impossibilities and violences within which Western thought is conceptually caught up; he is, however, not much of a political analyst.

\section{The Question of Home}

The world conjured in Spectres is 'going badly' and it is certainly going worse for some than for others. Derrida (1994: 81) lists ten 'plagues of the "new world order." Many of these resonate with our predicament today, although they are framed in the language of the time. The second plague highlights that the

massive exclusion of homeless citizens from any participation in the democratic life of States, the expulsion and deportation of so many exiles, stateless persons, and immigrants from a so-called national territory already herald a new experience of frontiers and identity whether national or civil (Derrida 1994: 81).

On my first reading of this sentence, perhaps reflecting our times, I understood this to be about people without access to accommodation and their exclusion from political 
participation. The term 'homeless citizens' called up, in my imagination, a person recognised as a member of the community, yet prevented from exercising their rights in practice. What then appears to be a juxtaposition of the predicament homeless people, i.e., those without permanent residence, with that of persons living outside of the state of their citizenship or lacking citizenship altogether, seems to highlight - however briefly - the political exclusion of several groups in the manner of being made homeless.

Yet, at the same time, presumably scarred by Theresa May's 'citizens of nowhere' jibe (2016), I am not convinced, am even scandalised, by calling persons living outside 'a socalled national territory' homeless, even if they are, to varying degrees, excluded from political participation. After all, what does it mean to assert that the 'new world order' produces those not in 'their' place as homeless? Am I (made) so, given that I am undoubtedly an immigrant in the UK? Was Derrida (made) homeless himself in France, given that his place of birth came to be an independent 'so-called national territory', or was he, as an 'over acculturated European' (made) more at home there than he would have been in Algeria? ${ }^{2}$ Where is home and how is this related to the movements of a person over their lifetime? How is it made and by whom? And are citizens in their proper 'so-called national territory', by definition, (made) at home?

The original text refers to 'citoyens sans abri (homeless)' (Derrida 1993: 135). ${ }^{3}$ That is, Derrida includes the English 'homeless' even in the French text. The difference, as far as I understand it, is that 'abri' signifies 'shelter' rather than 'home.' Thus, in the phrase 'homeless citizen' Derrida on the one hand includes persons identified as from elsewhere ('citizens') but on the other hand suggests that they lack something significant ('homeless'), namely a home (and not just shelter, as 'sans abri' appears insufficient to express the predicament). On this reading, the phrase exceeds the question of shelter, of the right to protection. The apparent assertion that 'so many exiles, stateless persons, and immigrants' are (made) deficient because of their dislocation strikes me as conservative, even if offered as a 'plague,' a political problem created by the 'new international order' (as opposed to being natural).

In Derrida's thinking the home is significant in relation to hospitality. He points out that 'I want to be master at home [...], to be able to receive whomever I like there', raising the possibility that 'one can become virtually xenophobic to protect one's own hospitality, the own home that makes possible one's hospitality' (Derrida 2000: 53). There can, in other words, be no 'hospitality, in the classic sense, without sovereignty of oneself over one's home' (Derrida 2000: 54). While this may be true as a matter of (classical) conceptual logic, the political application of the concept in thinking through the predicament of 'so many exiles, stateless persons, and immigrants' risks attributing a lack particular to their predicament to those not 'at home' in their 'so-called national territory'. Yet who is ever at home in this entirely fulfilled sense prior to engaging with others?

For Derrida (2001: 17) 'being at home with oneself (l'être-soi chez soi - l'ipséité meme - the other within oneself) supposes a reception or inclusion of the other which one seeks to appropriate, control and master according to different modalities of violence.' That is, there are clearly relations of power involved, even in an apparently benign opening of the home (Bulley 2017). There are two other points I want to draw out here, however. First, 
the classic understanding of the home as produced by Derrida is the home of the 'one.' That is, the home as a space of mastery is not just gendered but curiously empty, a space in which the host (singular) is in control. It is, in this way, the very opposite of what a state's territory may be. Second, the invocation of the home (or homelessness) produces the person not 'at home', in whichever way construed, as the problem. As Derrida (2000: 3 ) indeed points out, in one of the texts on hospitality, 'the question of the foreigner' is posed as though 'the foreigner were being in question' while the foreigner is also 'the one who puts me in question.'

The foreigner who accepts hospitality, which is always at the tension between being necessarily conditional in practice, despite the unconditionality required by its logic (Derrida 2000: 75-77), is in turn acceptable. It is the foreigner who refuses to understand themselves as homeless, even while the state and the community may be limiting their rights, who poses a risk. The foreigner in this sense might arrive as a future that poses an absolute risk in challenging the 'modalities of violence' that are part and parcel of the offer of hospitality. Derrida (2000: 125) does of course discuss the logic of the guest becoming the host, but I wonder whether more is to be said here about possibility of displacing the system of thought altogether, of challenging the power of 'being from here'

Derrida (2001: 12) was concerned about the situation of immigrants and refugees, criticising, for example, the 'absurdity' of French rules designed to control immigration. In relation to the phenomenon of interethnic wars, Derrida (1994: 82) highlights how these are out of step with the technological developments outlined above in relying on an outdated ontopology, that is, an 'axiomatics linking indissociably the ontological value of present-being $[o n]$ to its situation, to the stable and presentable determination of a locality, the topos of territory, native soil, city, body in general.' The association between geographic dislocation and homelessness relies on the same conceptualisation, but this is not commented on or related to ontopology.

Derrida's text associates various types of people who happen not to live on their 'so-called national territory' - 'exiles, stateless persons, and immigrants' - with political exclusion, albeit nevertheless referred to as 'citizens.' This linking of political exclusion with not being on one's national territory, whatever that may be, risks reinforcing that the problem is one of being an immigrant. That is, it is the production of political subjectivity of persons qua immigrants in the current world order that creates the lack leading to exclusion from political participation. At the same time, the very term 'homeless citizen, by bringing together the apparent poles of the opposition - immigrant versus citizen - starts to undermine the dichotomy, permits the possibility of (political) homelessness among those territorially at home. A Derridean reading of this dichotomy would surely highlight its falseness: immigrants may be full citizens and it is not necessary to migrate to become a non-citizen. It would also require an effective displacement, which seems to be lacking here. The false dichotomy thus masks the way in which the right and ability to participate fully in politics, while most easily taken from those seen not to be 'at home', is continuously challenged, even at risk, for all of us. 


\section{Finally}

Despite its philosophical denseness Specters is often considered part of Derrida's 'political turn. Clearly, Derrida shows us that the world is in a bad way, something that seems to have gotten only worse 25 years on. I would not advocate looking to Derrida's work for solutions or even for ready-made political analysis. Ultimately, I am not sure whether his 'plague' of the 'homeless citizens' is subtly insightful or stuck in conservatism. What I do note is that trying to puzzle this out has already clarified a number of questions for me that previously I was unaware I had and indeed forced me to think through the implications of various readings. My work thus continues to be inspired by Derrida: (re-)reading his texts often prompts me to explore new avenues of thinking, to question assumptions I had not realised I made. While his writings can be infuriatingly obscure at times, and indeed sometimes (seem to) overlook some of what is important politically, we need, more than ever, the courage to refuse the demand for solutions and to embrace the difficulty, indeed risk, of learning how to live beyond the apparent safety offered by knowledge.

\section{Deconstruction and Politics: Specters of Marx at Twenty-Five}

Antonio Y. Vázquez-Arroyo

Which Marxist spirit, then? ... we must never hide from the fact that the principle of selectivity which will have to guide and hierarchize among the "spirits" will fatally exclude in its turn.

—Jacques Derrida, Specters of Marx (1993: 144, 1994: 87).

1.

Among the many temptations of looking at Specters of Marx twenty-five years after it arrived in the Anglophone world is the desire to closely reread the text itself; or consider it in light of the ethical turn already under way when it was initially written and published, and that followed it. But it could also be an occasion to reconsider it in light of some of the preceding materials now available, especially Derrida's 1977 seminar Theory and Practice (2017) and the highly suggestive intimations it offers on the Marx's 'Thesis on Feuerbach' and Althusser, or the Heideggerian thematic already at work. Or, better yet, to reconstruct the significance of this text in light of subsequent developments within Marxism and critical theory, and even juxtapose that moment of epochal closure with the revival of a certain spirit of socialism in the interstices of the North Atlantic world, and rehearse the debates 
that followed it. It would take too much space even to briefly entertain all of these possibilities, albeit something would be said about some of these in a somewhat telegraphic way.

The present reflections are, accordingly, narrower in scope and take the occasion of rereading Specters of Marx to reconsider a question that animated its initial reception: the political import of deconstruction. By situating Specters of Marx in the context of Derrida's intellectual trajectory, the predicaments of power in which it intervened, and the light Derrida's subsequent political thought sheds on it, this question would be revisited once more, now that the proverbial dust has settled. ${ }^{4}$

\section{2.}

The radicalism of Derrida's early philosophical interventions soon raised questions about the political implications of deconstruction, especially as such radicalism was considered immediately critical, leftist and political, in its transatlantic reception. Peppered with social and political metaphors, something characteristic of this fertile moment in French intellectual history, the triad of works published in 1967 - Speech and Phenomena, Of Grammatology, Writing and Difference - that established Derrida's reputation exhibited a de-differentiation of genres that transgressed the academic boundaries between the philosophical and the literary. Virtuoso performances, these radical gestures bent on de-differentiation found their philosophical apogee in Dissemination and Margins of Philosophy; Glas was its most extravagant instantiation. Formal radicalism was thus deeply intertwined with an avowed antinomian vocation well-steeped in German phenomenology that married polemic with philosophical acumen, a daring tone with a coruscating intelligence and capacity for close reading, that few could match.

The upshot: work that combined literary skill with philosophical depth and rhetoric and openly defied academic forms and the protocols of logic and the accuracy of evidence, textual or factual, associated with it. Emancipation from these forms, often perceived as deadening or stale by its critics, and as makers of rigor by its defenders, was experienced as liberating or exasperating almost in equal measure. The nimbus surrounding these early works, their rhetorical skill, sheer originality and radicalism, cast a spell over his followers; but, equally powerfully, cast a shadow of instant suspicion among critics. Moreover, in its arrival at American shores, it was assumed by both defenders and critics that deconstruction's philosophical radicalism was immediately critical and political, leading to conceited claims by adherents and hysterical reactions by critics.

This polarizing reception could account for Derrida's marginality in French intellectual life during those years and marked his relationship to academic philosophy from early on. But it reverbated across the Atlantic, as Derrida made his name in the same transatlantic set of concatenations that led to the rise of the equally polarizing form of theoretical discourse known as Theory, a transatlantic construction that in the United States is perceived as French, but that many in France see as an American invention (cf. Cusset 2008). A discourse of elisions, borrowings and de-differentiations, that has proven as polarizing as Derrida's own work, and for which Derrida emerged as a central signpost. 
This is not the place to elaborate on the history of Theory, however; suffice it to simply acknowledge it as a central determinant of the question about the political implications of deconstruction, whose radicalism at the level of philosophical discourse, a theoretical maximalism if there ever was one, nevertheless dodged questions about its political implications, thus inviting both friendly and hostile speculation about whether or not these theoretical maximalisms found a correlate in a maximalist commitment to emancipation, or whether it was a theoretical feint whose aporias irremediably led to either nihilistic quietude or the North Atlantic, bien pensant, left-liberalism embodied in the ethical politics that eventually defined Derrida's interventions on political questions (on ethical politics, including Derrida’s, see Vázquez-Arroyo 2016: 56-57, 178-180).

\section{3.}

Deconstruction's political ambiguity was compounded by Derrida's long silence on Marx, the radical political thinker per excellence, and tacit benchmark for any radicalism purporting to be political. Derrida's hesitations to engage with Marx's corpus were notorious; a reluctance eloquently expressed and justified in interviews, but that nevertheless remained deeply puzzling for admirers and critics alike. In a French context in which prior to the 'de-marxification' of intellectual life, from the mid-seventies on, Marxism enjoyed a period of effervescence, and variations of western Marxism flourished at the hands of Lefebvre, Althusser, Balibar and Poulantzas, Derrida claimed not to find space publicly to engage Marx. In an interview with Marxist literary critic Michael Sprinker, Derrida (2002: 153) spoke about being 'intimidated, but protesting inside!' by an intellectual milieu in which his line of questioning, references and signposts were not well received. Moreover, in addition to theoretical and philosophical reservations about what Althusser and his disciples were doing next door at the École Normale Supérieure (ENS), there were political reasons, too: an anxiety best described as the fear of guilt by association, of tacit complicity with the rabid anti-communism of an emergent anti-totalitarian front, which he suggested was an even deeper reason for his silence. Unwittingly striking the pose of a beautiful soul, he retrospectively states:

[...] I didn't wish to formulate [...] political objections and risk having them confused with conservative reticence. I didn't want that. I realize that others (few, in truth) found a clear way to take that risk which I didn't take. But I would say also that they did so in a code and according to an axiomatic with which I wanted nothing to do, which were not in tune with the discourse that I was elaborating. That is the deepest reason for my silence, rather than shyness or intimidation. I never let myself be intimidated when I can say what I want with the desired rigor. Basically some of my silences or abstentions still today may be explained thus: the code in which I am asked to express myself seems laden with unacceptable presuppositions (Derrida 2002: 163). 
So silent he remained.

Yet Derrida's teaching was a different matter. In the late seventies, at a time in which the tide was already turning in France, and anti-Marxism solidified in the aftermath of the backlash against the Common Program of the socialist and communist parties, and the emergence of an anti-totalitarian moment and the corollary retrieval of French liberalism polemically oscillating between the centre and the right, Derrida taught a seminar at the ENS on the thematic of theory and practice. Therein, he devoted some time to a consideration of Marx's 'Theses on Feuerbach' (duly dubbed 'un évènement'), notably more time to Althusser's powerful engagement with the question of the possibility of a Marxist philosophy in light of how Marx's strictures in the famous eleventh thesis were received and interpreted in the French Communist Party (PCF), and, of course, plenty of time to Heidegger's ruminations on the question (Derrida 2017). While not yet ascendant, themes that would become central in Derrida's work are already present, say, intimations of responsibility and the idea of deferred futurity contained in his famous phrase 'to come' (à venir).

But for all its incipient adumbrations, and the acuity of his interpretation of Althusser's idea of Theory and the intricate engagement with Heidegger, the seminar says very little of substance about Marx. Occasional insightful remarks on the 'Theses on Feuerbach' aside, the treatment of Marx is mostly cursory and at a distance from the increasingly present (and irritating) question of the politics of deconstruction, or deconstruction's relationship to politics beyond any purportedly deconstruction of the political. A question that the master thinker at first deftly, eventually awkwardly, dodged. So did many a disciple. Indeed, while purportedly concerned with 'the political,' Derrideans tenaciously resisted any politicization of deconstruction. Rebuffing efforts to politicize deconstruction beyond the platitudinous, like, say, Gayatri Spivak's, the emphasis was instead placed on treatment of the political as yet another concept in need of deconstruction; as if by doing so, somehow, the intersections between deconstruction and politics would be staged, and the nagging question of whether or not the philosophical radicalism of the early texts yielded an equally radical and maximalist politics would dissipate (see Fraser 1984). The truncated afterlife of these discussions, centred at the Political Seminar at Cérisy and led by Jean-Luc Nancy and Philippe Lacourt-Labarthe, further tells the tale.

Yet the nagging question persisted throughout the eighties. And as two transatlantic scandals, that of Heidegger's Nazism and De Man's collaborationism, left an indelible mark in Derrida's intellectual and political itineraries, the need to establish deconstruction's political credentials was thus intensified and became imperative. ${ }^{5}$ The publication of Specters of Marx was deeply overdetermined by these questions and debates and by a transatlantic conjuncture defined by intellectual and political reaction.

4.

Published in the context of the collapse of Soviet communism, neoliberal consolidation, and the North Atlantic victory of the cold war, which declared the advent of a new world 
order - in the USA this was emblematized by Fukuyama's thesis on the end of history and the triumph of liberal democracy; in France, this was the hour of liberalism, when at last Gaullism, Jacobinism and Communism were put to rest and France could be a normalized liberal-democracy in the North Atlantic world - Specters of Marx finally delivered Derrida's long-awaited engagement with Marxism and political thought. Here notions of responsibility and inheritance are central, but the most important notion is that of spectrality, which becomes yet another signature concept/thematic bearing all the playful undoing of binaries associated with his original coinage différance.

Still: why then and not before? Preemptively, Derrida (1993: 144-145, 1994: 88) writes about this 'belated-rallying-to-Marxism': 'Already I hear people saying: "You picked a good time to salute Marx!" Or else: "It's about time!" "Why so late?" In his defence, Derrida briefly dwells on the virtues of 'contretemps,' a virtue consistent with the Shakespearean motif about time being out of joint; but more importantly, and tellingly, is how the possibility of engaging Marx publicly, without imposed axioms or unacceptable presuppositions, was at last open at a moment in which Marx, Marxism and socialism were considered dead or obsolete. Yet, what Derrida saw as an opening for an unencumbered engagement with Marx in his own terms, others saw as sheer opportunism in a thinker beleaguered by the fumbles associated with the Heidegger and De Man affairs who could at last appear to take a political position that risked little and ultimately remained ensconced in his philosophical citadel. Regardless, the upshot was the same: a tacit but clear affirmation of the post-Marxist liberal moment in radical guise.

Indeed, in Specters of Marx Derrida claims at once to mourn Marxism's passing and to redeem its promise by penning passages that read like an éloge to Marx, while taking the opportunity to buttress the political and critical credentials of deconstruction by proclaiming it heir to 'a certain spirit of Marxism' that empties Marxism of any critical and political import beyond the transatlantic liberal moment that it addresses:

...what is called deconstruction, in the figure that it initially took over the course of these last decades, namely the deconstruction of the metaphysics of the "proper," of logocentrism, linguisticism, phonologism, the demystification or the desedimentation of the autonomic hegemony of language (a deconstruction in the course of which is elaborated another concept of the text or the trace, of their originary technization, of iterability, of the prosthetic supplement, but also of the proper and of what was given the name exappropriation). Such a deconstruction would have been impossible and unthinkable in a pre-Marxist space. Deconstruction has never had any sense or interest, in my view at least, except as a radicalization, which is to say also in the tradition of a certain Marxism, in a certain spirit of Marxism (Derrida 1993: 151, 1994: 92).

Heaving with appreciation of the 'event' that Marx and Marxism represented, Derrida's text shows a commitment to retrieve Marx at a moment in which its obsolescence 
was well-nigh universally proclaimed. But 'this gesture of fidelity to a certain spirit of Marxism,' Derrida (1993: 148, 1994: 90) quickly added, demands a selective inheritance in which the category of the heir becomes distended in a universalization that prefigures Derrrida's subsequent theorization of an '(im)possible responsibility'. But this is no mere rhetorical quirk. Rather, it is the result of distending the notion of inheritance to make plausible the claim about deconstruction as Marxism's radical heir. ${ }^{6}$

Clinching the critical valences of deconstruction by wedding it to Marxism - even at one point characterizing it as 'faithful to a certain spirt of Marxism' (Derrida 1993: 128, 1994: 75) - similarly calls for the latter to be cut down to size:

To continue to take inspiration from a certain spirit of Marxism would be to keep faith with what has always made of Marxism in principle and first of all a radical critique, namely a procedure ready to undertake its self-critique. This critique wants itself to be in principle and explicitly open to its own transformation, re-evaluation, self-reinterpretation. Such a critical "wanting-itself" necessarily takes root, it is involved in a ground that it not yet critical, even if it is not, not yet, pre-critical. This latter spirit is more than a style, even though it is also a style. It is heir to a spirit of the Enlightenment which must not be renounced. We would distinguish this spirit from other spirits of Marxism, those that rivet it to the body of Marxist doctrine, to its supposed systemic, metaphysical, or ontological totality (notably to its "dialectical method" or to "dialectical materialism"), to its fundamental concepts of labor, mode of production, social class, and consequently to the whole history of its apparatuses (projected or real: the Internationals of the labor movement, the dictatorship of the proletariat, the single party, the State, and finally the totalitarian monstrosity) (Derrida 1993: 145-146, 1994: 88).

As the reduction and dodging of these passages make clear, Derrida's inheritance from Marxism was and remained what Terry Eagleton (1999) mordantly but accurately once called a 'Marxism without Marxism.' Thus dirempted from its political vectors, philosophical and conceptual armature, Marxism becomes a spectral, theoretically empty and politically toothless placeholder incapable of the work of comprehension and critique that defined its earthly claims to concreteness.

That this is so is also clearly seen in Derrida's formulation of spectrality, a notion shot through and thoroughly vitiated by Heidegger's Geistlich and its concomitant retreat from the political and historical dilemmas, determinations and determinants of actualization that are constitutive of, say, Hegel's Geist, which further raised questions not just about the actual political import of deconstruction's radicalism, but also the claim of deconstruction as Marxism's heir.7 Truer to the vocation of an aloof enlightened critic vindicated in the previous passages, this inheritance remained truncated, abstract. Once emptied of any account of historical materialism, historical determination and capitalism, Derrida's inheritance of Marx shrouded a typically left-liberal defensive politics capable of denouncing 
this or that injustice - say, the laundry-list of 'plagues' paraded in Specters of Marx - but incapable of attempting to actually map and relate injustices as part of an effort to comprehensively think through their actualization, systematic nature and patterned imperatives, and the political dilemmas involved. The fundamental lesson of Specters of Marx is clear enough; and yet, twenty-five years later, it bears repeating: theoretical radicalism is never immediately critical, let alone political.

\title{
Specters of Friendship and the New International
}

\author{
Dan Bulley and Bal Sokhi-Bulley
}

Specters of Marx is rich, provocative and deeply frustrating. The same could be said of Derrida's work in general, especially when he speaks or writes about international politics. The frustration of Specters arises partly from Derrida's regrettably commonplace observations and critiques. For instance, in his defence of international institutions and international law, which he describes as perfectible and progressive, he states that 'supposedly universal international law remains, in its application, largely dominated by particular nation-States' (Derrida 1994: 83). Meanwhile, the potentiality of democracy, humanitarianism and human rights is asserted, but they cannot be explored without confronting head on the burden of international, or 'foreign,' debt (Derrida 1994: 93). There is little here that anyone of a broadly leftist or liberal bent would, or even could, disagree with. But equally there is nothing new or startling. Yet there is a richness and a provocation to be found throughout Specters. We concentrate on a term that has been paid little attention. Derrida's minimal reference to 'friendship' in Specters as a key aspect of the 'new International' offers, we suggest in this article, a radical way to imagine the future(s) of international politics.

It is perhaps significant that the ten 'plagues' of the liberal world order drawn out by Derrida are rarely referred to by International Relations (IR) scholars. Whilst they were all important issues in 1993, and indeed remain significant dangers today, they are slightly disappointing. Beyond the superb neologism of 'ontopology' to describe the conditions of apparently inter-ethnic war (Derrida 1994: 82), which David Campbell (1998a: 33-81) used so well to analyse the Bosnian conflict of the 1990s, the plagues offer little insight that is unavailable elsewhere. Unsurprisingly, there is no anticipation of what will define the subsequent decade through a war on terror, and no reference to climate change or environmental damage, beyond the parenthetical hint which 'leave[s] aside' the question of animal life (Derrida 1994: 85). And yet, in his critique of Francis Fukuyama and the declared victory of liberal democracy over communism, Derrida (1994: 85) rightly points powerfully to something that is 'out of joint' in the progressive triumphalism of the early post-Cold War era: 'never before have so many men, women, and children been subjugated, starved, or exterminated on the earth.' It is this observation which links together 
all the paradoxical elements of the liberal international - apparent progress alongside the rampant violence of the nation-state form, its techno-scientific and military power, extractive forms of capitalism and the inequality it generates. And it is this which leads Derrida into his far more influential observation on the 'New International,' an idea that has been taken up by IR scholars (Campbell 1998b: 516-7; Edkins 2003: 256; Vaughan-Williams 2005: 175-177).

Derrida (1994: 96) calls the New International forth as a 'counter-conjuration, part of a spectral critique of the state, the nation and international law as currently constituted. As he explains earlier in Specters, to 'conjure' has a dual meaning, a split purpose: on the one hand it means to conspire, to magically invoke to presence that which is absent; on the other, it is to exorcise and repulse a spirit already called to presence (Derrida 1994: 41, 47). A counter-conjuration therefore appears as a double-contradiction, calling and banishing without a final idea as to the possibility of presence. Thus, Derrida (1994: 85) is firmer on what the new International is not whilst struggling, deliberately and performatively, to bring to presence what it is:

The 'New International' is not only that which is seeking a new international law through these crimes. It is a link of affinity, suffering, and hope, a still discreet, almost secret link, as it was around 1848, but more and more visible, we have more than one sign of it. It is an untimely link, without status, without title, and without name, barely public even if it is not clandestine, without contract, 'out of joint', without coordination, without party, without country, without national community (International before, across, and beyond any national determination), without co-citizenship, without common belonging to a class.

In a time when populist nationalism abounds with talk of globalist conspiracies, often including a barely disguised anti-semitism, ${ }^{8}$ it is fascinating to see Derrida conjuring his own almost secret, conspiratorial invocation of a global linkage based in 'affinity, suffering and hope.' However, unlike such populist conspiracies, and contrary to visions of cosmopolitan democracy, Derrida's New International has no party or institution to organise it and does not herald a new form of 'common belonging' based in humanity or global co-citizenship. Indeed, as Derrida strives to give positive definition to the link he is describing, he alights on the term 'friendship': this New International is 'what calls to the friendship of an alliance without institution' (Derrida 1994: 85-6, emphasis added).

This use of 'friendship' is not commented upon in the IR literature inspired by the New International in Specters. Rather, the preference is for the terms Derrida uses in his description of the New International in an interview with Richard Beardsworth from 1994 (entitled 'Nietzsche and the Machine'), where he outlines a 'bond between singularities [...] a form of political solidarity opposed to the political qua a politics tied to the nation-state' (Derrida 2002: 220). What stands in place of friendship here is 'solidarity', a term Derrida never unpacks or explains and which plays little role in his wider thought. But it appears more tangible that friendship, more immediately political perhaps, to IR 
scholars. Moreover, the neglect of 'friendship' is not altogether surprising given that this is the only time Derrida uses the word in Specters. It is never mentioned again and hardly appears central to his analysis of how we might critically inherit the politics and legacy of Marx and Marxism. It remains a spectral presence. But a year after the appearance of Specters, in 1994, his major text Politiques de l'amitié was published in France, translated into English as Politics of Friendship (Derrida 1997). The two texts are contemporaneous. Derrida explained the relation between them later: both books attempt 'to re-think what the political is [...] I'm not proposing a new political content within the old frame but trying to re-define, or to think differently, what is involved in the political as such' (Derrida 1997b).

But why choose friendship to describe this link of affinity across national determinations and without common belonging? Why rethink the political through friendship at all? This is because, for Derrida, Western political thought from Plato and Aristotle has intimately tied democracy, justice and the political to the concept and practice of friendship. This link has now withered away with modernity and, despite having forgotten the deeply 'phallocentric' concept of friendship, we arrive from it at a kind of canonical definition of politics (including the nation, state, territory, sovereignty, representation, democracy). It is this canonical model of politics which Derrida (1997b) is signaling beyond, through the New International - and its call to friendship - in Specters. In a classically Derridean mode, he is looking back in order to push at the limits of received understanding, our inheritance of the political. His work on friendship follows the same technique of critical inheritance to which he subjects the Marxist legacy:

An inheritance is never gathered together, it is never one with itself. Its presumed unity, if there is one, can consist only in the injunction to reaffirm by choosing. 'One must' means one must filter, sift, criticize, one must sort out several different possibles that inhabit the same injunction. And inhabit it in a contradictory fashion around a secret. (Derrida 1994: 16).

It is precisely this technique, or deconstructive style, that makes Derrida so frustrating and exhilarating, both deeply conservative and radical at the same time. He wants to critically sift the arcane link between politics and friendship, pushing against assumptions of phallocentrism and commonality, ties of territory, borders and place, identifying the fissures that can explode the boundaries of what is thought politically possible - and possible for international politics.

Friendship is an untimely concept. Modernity, as Graham Smith (2011a: 3) notes, has long since overcome friendship; we have lost something in the process and must 'relocate' it. But friendship will always be timely for international politics and the discipline of IR, never more so now as the USA's apparent hegemony is slipping and its leaders proceed to make enemies of friends and friends of enemies. If we take Carl Schmitt's (2007: 26) understanding of the political as revolving around the reductive distinction between 'friend and the enemy', then international politics is defined by friendship and enmity. Yet friendship itself is barely mentioned by Schmitt (2007: 51-2), and only as something 
that does not negate the distinction between friend and enemy. Similarly, friendship in IR has been given very little attention from those scholars drawing on Derrida and those who leave no space for him in their attempts at 'relocating' friendship (Smith 2011). As a recent edited collection noted, though never entirely absent from the discipline, friendship has been treated loosely 'without a clear definition or systematic analysis, often used simply to describe 'non-confrontational or harmonious interstate relations' (Oelsner and Koschut 2014: 3). IR's relocation of friendship faces two limits: ${ }^{9}$ first, that friendship is an identifiable, already extant relation in international politics; this makes friendship merely a cynical façade, reducing it to contractual 'friendly relations' between states (Devere et al 2011). Second, and implied within the first, friendship in IR is limited to states - states are the sole subjects of international friendship.

Thus, leaving friendship to non-Derrideans has its costs. Although some contributions encourage response to a crucial question which animates Derrida's own overtly political texts, 'how should we respond to others?' (Devere and Smith 2010: 351; Berenskoetter 2007: 657; Derrida 1988: 638), most of the recent rethinking of friendship in IR has remained stuck within the conventional frame of the political: state, nation, territory and sovereignty (for example, see Devere et al 2011; Roschin 2011; Berenskoetter 2007; Van der Zweerde 2007). The subjects of friendship are deemed to be states, their leaders or their citizens. Even Smith's focus on friendship as 'a means to conceptualise the bonds between person and person' as a structure for politics (Smith 2011a: vii, 1) is reduced to a framework oriented entirely around the state. ${ }^{10}$ The aim of much of this literature has been to tame friendship, to 'delineate' its content as a 'distinct category of interstate relations' (Oelsner and Koschut 2014: 4). To delineate, to place precise boundaries around friendship, is close to the opposite of Derrida's idea of inheriting political concepts and practices. For instance, Specters demonstrates him reveling in the heterogeneity of the knowledge we inherit, affirming its capacity to be interpreted, transformed and recreated. Reading Blanchot's injunction against the attempt to unify and purify the scientific Marx, Derrida (1994: 34) affirms a different reception of knowledge that 'overturns and overflows its received idea.' This is Derrida's aim with the New International and the politics of friendship, to conjure the canonical reading of the political in order to overturn and overflow its boundaries and delineations.

What Derrida does in opening up friendship and the international is not, then, a matter of demarcating new programmes or institutionalisations of commonality. Rather, his aim is to inscribe the political with futurity, with the animating possibility and promise of the 'to come' (Derrida 1994: 89); '[f]riendship is never given in the present; it belongs to the experience of waiting, of promise, or of commitment' (Derrida 1988: 636). And this means his understanding of friendship is about a breaking as much as a bonding, estrangement from as much as joining with the family, the neighbour and the nation:

This is not to wage war on them and to see evil therein, but to think and live a politics, a friendship, a justice which begin by breaking with their naturalness or their homogeneity, with their alleged place of origin. Hence, which begin where the beginning divides (itself) 
and differs, begin by marking an 'originary' heterogeneity that has already come and that alone can come, in the future, to open them up. If only unto themselves (Derrida 1997a: 105).

The questioning, critique, overflowing and breaking of boundaries then includes the very bonds by which we may conventionally understand 'friendship.' This contradictory movement toward and away, befriending and estranging, is the only way to maintain the openness of the new International - to ensure, in fact, that it does not become a 'solidarity' (from the Latin, in solidium, meaning 'for the whole'), but maintains its division and difference from itself. A friendship of breaking and bonding ensures that the New International remains without institution, without common belonging.

The vision of the international offered by Derrida is therefore unlike anything available in the voluminous literature on cosmopolitanism, which strives towards a more or less institutionalised unity. But this does not mean it is without organisation and a demand for action - in fact, this is what links his vision of the political to a 'spirit of Marxism' he critically inherits. The potentiality, the futurity, Derrida (1994: 89) discovers in democracy, justice, hospitality and friendship resides precisely in their 'promise':

And a promise must promise to be kept, that is, not to remain 'spiritual' or 'abstract,' but to produce events, new effective forms of action, practice, organization, and so forth. To break with the 'party form' or with some form of the State or the International does not mean to give up every form of practical or effective organization. It is exactly the contrary that matters to us here.

The politics of friendship that is 'called to' by the New International then, is one of action, practice and organization, without allowing itself to become uncritical, ossified, natural, institutional. It calls for strategic, temporary, flexible solidarities that involve bonding and breaking, containing and overflowing, in order to retain openness and promise.

The utility of such a hazy vision for the new International is then about a 'response-ability' (Haraway 2016: 2; see also Derrida 1988: 638) towards the other and to a different version of politics - and to respond with a grievance against 'givens, and the most accredited concepts of politics and the standard interpretation of friendship' (Derrida 1997a: xi). Yet the utility, and precisely how we respond, must also remain unclear, something to be taken up in particular ethico-political contexts through strategic practices and interventions. Some of these may appear obvious. For example, the promise of friendly bonds forged through the arrival of Venezuelan refugees in Brazil and Colombia, or Syrian refugees in Greece and Germany appears an uncontroversial practice responding to these ideas. But the 'spirit of Marxism' and the logic of inheritance means applying the same critical sifting to Derrida's own thought and legacy. We must transform and recreate the International anew, following the weaknesses of Derrida's vision. As already mentioned above, his idea of the new International remains profoundly anthropocentric; in 1993, he deliberately left aside the question of the 'animal,' despite acknowledging that it will 'become massively unavoidable' (Derrida 1994: 85). But in a time when the human relation to, and reliance 
upon, the non-human biosphere has never been more apparent, such anthropocentrism is not only 'untimely' but outdated and irresponsible. The promise and utility of the new International perhaps lies in sifting out the monopoly of the human bond, overflowing those boundaries, acknowledging existing friendships and making new ones with the material and 'non-human.' To inherit the spirit of both Marx and Derrida, perhaps the new International's promise lies in, to borrow Donna Haraway's (2016) subtitle, 'making kin in the Chthulucene.'

\section{Notes}

1 [Note by Zehfuss] My current thinking on Derrida is influenced by recent conversations with Dan Bulley and Nick Vaughan-Williams. I was also inspired to rethink some of my reactions to Spectres of Marx in response to being on a roundtable on the book with Simon Glendinning and Robert Eaglestone at the LSE Festival 'New World (Dis)Orders,' London School of Economics Forum for Philosophy the podcast for which is available at https://soundcloud.com/lsepodcasts/lse-festival-2019-the-haunting?in=lsepodcasts/ sets/lse-festival-2019-new-world. I am particularly grateful to Dan Bulley for his insightful comments on a draft of this paper.

2 [Note by Zehfuss] Derrida (2000: 141-147) discusses religious differentiation of the category of a 'French person without French citizenship' (2000: 143).

3 [Note by Zehfuss] Although Spectres was produced as the opening address for an international conference at the University of California, Riverside, Derrida wrote it in French. Peggy Kamuf translated the text while Derrida continued to work on it (Peeters 2013: 462-3).

4 [Note by Vázquez-Arroyo] Indeed, now one is struck by how Fredric Jameson’s (2009: 127-178) 'Marx's Purloined Letter' remains the most formidable engagement with it out of the Marxist tradition. The other enduring treatment comes from within North American political theory: Wendy Brown's (2001: 144-155) 'Specters and Angels.' Yet the jottings that follow largely disagree with both; but Brown's and Jameson's interpretations were indispensable stimuli for my own.

5 [Note by Vázquez-Arroyo] For a discussion of these affairs, see Peeters (2013: 379-401).

6 [Note by Vázquez-Arroyo] See Vázquez-Arroyo (2016: 150-160). Consider the following distended formulations: 'The responsibility, once again, would here be that of an heir. Whether they wish it or know it or not, all men and women, all over the earth, are today to a certain extent the heirs of Marx and Marxism. That is, as we were saying a moment ago, they are heirs of the absolute singularity of a project - or of a promise - which has a philosophical and scientific form' (Derrida 1993: 149, 1994: 91); 'And whether we like it or not, whatever consciousness we have of it, we cannot not be its heirs. There is no inheritance without a call to responsibility. An inheritance is always the reaffirmation of a debt, but a critical, selective, and filtering reaffirmation, which is why we distinguished several spirits' (Derrida 1993: 150, 1994: 91-92).

7 [Note by Vázquez-Arroyo] See Rose (1993: 65-87). Analogously, as Jameson (2009) acutely observed, historicism hardly makes an appearance in the book, but given Derrida's consistent hostility to historicizing practices, one would have expected it to figure more prominently. Indeed, Derrida's (1993: 125, 1994: 74-75) one reference to it consists of, literally, a parenthetical call for 'another historicity'. Pace Geoffrey Bennington, Rose (1993) and Peter Dews (2006) remain two of Derrida's best philosophical critics. Chief gendarme of 'the Derrida international' (Peeters 2013: 478-494), Bennington chides heretical deviations, provides the correct albeit duly deconstructed line in interpreting Derrida's thought, and guides the faithful with a zeal and fidelity to the Derrida-Event that not even Marx's 'sons' in their heyday could match. Cf. Derrida (1999).

8 [Note by Bulley and Sokhi-Bulley] See, for example, the invidious website: http://www.globalistagenda.org/

9 [Note by Bulley and Sokhi-Bulley] See the Special Issue of International Politics on 'Friendship in International Relations' (edited by Oelsner and Vion 2011).

10 [Note by Bulley and Sokhi-Bulley] Smith (2011b: 23) suggests three broad sites of friendship within the international community - within states, between states, and across states. 


\section{References}

Berenskoetter, F. 2007. 'Friends, There Are No Friends? An Intimate Reframing of the International.' Millennium: Journal of International Studies 35 (3): 647-676.

Brown, Wendy. 2001. Politics Out of History. Princeton: Princeton University Press.

Bulley, Dan. 2017. Migration, Ethics \& Power. London: Sage.

Campbell, D. 1998a. National Deconstruction: Violence, Identity and Justice in Bosnia. Minneapolis: University of Minnesota Press.

1998b. 'Why Fight: Humanitarianism, Principles, and Post-structuralism' Millennium: Journal of International Studies 27(3): 497-521.

Cusset, F. French Theory. Transl. Jeff Fort. Minneapolis: University of Minnesota Press.

Derrida, J. 1988. 'The Politics of Friendship.' Journal of Philosophy 85 (11): 632-644.

1992. The Other Heading: Reflections on Today's Europe. Transl. Pascale-Anne Brault and Michael B. Naas. Bloomington: Indiana University Press.

Galilée.

1993. Spectres de Marx: L'État de la dette, le travail du deuil et la novelle International. Paris:

1994. Specters of Marx: The State of the Debt, the Work of Mourning, \& the New International.

Transl. Peggy Kamuf. New York: Routledge.

1997a. Politics of Friendship. Transl. G. Collins. London: Verso.

.1997b. 'Politics and Friendship: A Discussion with Jacques Derrida.' At http://hydra.humanities.uci.edu/Derrida/pol+fr.html [Accessed on 2 July 2019].

. 1998. Of Grammatology. Transl. Gayatri Chakravorty Spivak. Corrected edition. Baltimore: The Johns Hopkins University Press.

. 1999. 'Marx \& Sons.' In Michael Sprinker (ed), Ghostly Demarcations. London: Verso, pp. 213-269.

2000. Of Hospitality: Anne Dufourmantelle invites Jacques Derrida to respond. Transl. Rachel Bowlby. Palo Alto: Stanford University Press.

Routledge.

2001. Cosmopolitanism and Forgiveness. Transl. Mark Dooley and Michael Hughes. London:

2002. Negotiations: Interventions and Interviews, 1971-2001. Transl. Elizabeth Rottenberg. Palo Alto: Stanford University Press.

2017. Théorie et pratique. Paris: Galilée.

Devere, H and G M Smith. 2010. 'Friendship and Politics.' Political Studies Review 8 (3): 341-356.

Devere, H, S Mark and J Verbitsky. 2011. 'A history of the language of friendship in international treaties.' International Politics 48 (1): 46-70.

Eagleton, T. 1999. 'Marxism without Marxism.' In Michael Sprinker (ed), Ghostly Demarcations. London: Verso, pp. 83-87.

Edkins, J. 2003. 'Humanitarianism, humanity, human.' Journal of Human Rights 2 (2): 253-258.

Fraser, N. 1984. 'The French Derrideans.' New German Critique 33: 127-154.

Fukuyama, Francis. 1992. The End of History and the Last Man. Harmondsworth: Penguin. 
Glendinning, Simon. 2011. Derrida: A Very Short Introduction. Oxford: Oxford University Press. Haraway, D. 2016. Staying with the Trouble: Making Kin in the Chthulucene. Durham: Duke University Press.

Jameson, F. 2009. Valences of the Dialectic. London: Verso.

Magnus, Bernd and Stephen Cullenberg. 1994. 'Editors' Introduction.' In J Derrida, Specters of Marx: The State of the Debt, the Work of Mourning and the New International, Transl. Peggy Kamuf. New York: Routledge.

May, Theresa. 2016. 'Theresa May's conference speech in full. The Telegraph, 5 October.

Oelsner, A and S Koschut. 2014. 'A framework for the study of international friendship.' In S Koschut and A Oelsner (eds), Friendship and International Relations. Basingstoke: Palgrave Macmillan, pp. 3-33.

Oelsner, A and A Vion. 2011. 'Introduction Special Issue: Friendship in international relations' International Politics 48 (1): 1-9.

Peeters, Benoît. 2013. Derrida: A Biography. Transl. Andrew Brown. Cambridge: Polity.

Rose, G. 1993. Judaism and Modernity. Oxford: Blackwell.

Roshchin, E. 2011. 'Friendship of the enemies: Twentieth century treaties of the United Kingdom and the USSR' International Politics 48 (1): 71-91.

Schmitt, C. 2007. The Concept of the Political. Transl. G. Schwab. Chicago: University of Chicago Press.

Smith, G M. 2011a. Friendship \& the Political: Keirkegaard, Nietzsche, Schmitt. Exeter: Imprint Academic.

2011b. 'Friendship and the world of states.' International Politics 48 (1): 10-27.

Van Der Zweerde, E. 2007. 'Friendship and the Political'. Critical Review of International Social and Political Philosophy 10 (2): 147-165.

Vaughan-Williams, N. 2005. 'Protesting Against Citizenship.' Citizenship Studies 9 (2): 167-179.

Vázquez-Arroyo, Antonio Y. 2016. Political Responsibility. New York: Columbia University Press.

Zehfuss, Maja. 2007. Wounds of Memory: Politics of War in Germany. Cambridge: Cambridge University Press.

2015. '(Nuclear) War and the Memory of Nagasaki: Thinking at the (Impossible) Limit.' Thesis Eleven (special issue on Cultural Theory and Nuclear Bombs) 129: 57-71.

\section{About the authors}

Maja Zehfuss is Professor of International Politics at The University of Manchester. She is the author of three research monographs. Her most recent book, War and the Politics of Ethics (Oxford University Press 2018), was awarded an honourable mention for the BISA Susan Strange Prize 2019. She co-edits Global Politics: A New Introduction, $3^{\text {rd }}$ edition (Routledge 2019) with Jenny Edkins. She is the Chair of the Editorial Committee for Manchester University Press and is one of the incoming co-editors of the Review of International Studies. She has written on war, ethics, memory, international theory, subjectivity and vulnerability. Her current work explores the problematisation of migration. 
Antonio Y. Vázquez-Arroyo is an Associate Professor in the Department of Political Science at Rutgers University-Newark, where he teaches political theory. He is the author of Political Responsibility: Responding to Predicaments of Power (Columbia University Press, 2016). His writing has appeared in Constellations, Contemporary Political Theory, Historia y Sociedad, New Political Science, Perspectives on Politics, Political Theory, Polity, Postcolonial Studies, Radical Philosophy and Theory \& Event. Currently he is finishing a book on the dialectical legacy of critical theory, tentatively titled Wayward Dialectics. He continues to work on the intersections between catastrophes and political life, an intellectual portrait of Sheldon S. Wolin's political thought and on transatlantic political thought.

Dan Bulley is Reader in International Relations and Director of the Centre for Global Politics, Economy and Society (GPES) at Oxford Brookes University. His research explores the role of ethics, power and space in international politics, with a particular focus on hospitality, migration, global cities, refugee camps and the European Union. He has published three books, Ethics as Foreign Policy: Britain, the EU and the Other (Routledge, 2009), Migration, Ethics and Power: Spaces of Hospitality in International Politics (Sage, 2017) and, co-edited with Jenny Edkins and Nadine El-Enany, After Grenfell: Violence, Resistance and Response (Pluto Press, 2019).

Bal Sokhi-Bulley is Senior Lecturer in Law and Critical Theory at the University of Sussex. Her research has examined critical approaches to rights and resistance, with a focus on EU governance and migration, and critical research methods in human rights law. Her monograph, Governing (Through) Rights (Hart, 2016) adopts a Foucauldian frame to discuss rights as technologies of governmentality within domestic, regional and international spaces. Her current work uses poststructural theory to look at rights as a relational ethics of friendship. 


\title{
A Importância Política da Desconstrução-0s Limites de Derrida?: Um Fórum sobre os Espectros de Marx de Jacques Derrida depois de 25 anos, Parte I
}

\begin{abstract}
Resumo: Jacques Derrida entregou a base de os Espectros de Marx: O Estado da Dívida, a Obra do Luto e a Nova Internacional como discurso plenário na conferência 'Para onde o marxismo?', na Universidade da Califórnia, em Riverside, em 1993. A versão mais longa do livro foi publicada em francês no mesmo ano e em inglês e português no ano seguinte. Uma década após a publicação dos Espectros, as análises de Derrida provocaram uma grande literatura crítica e convidaram tanto a consternação quanto a celebração de figuras como Antonio Negri, Wendy Brown e Frederic Jameson. Este fórum procura estimular novas reflexões sobre Derrida, desconstrução e Espectros de Marx, considerando como futuro do passado anunciado pelo livro se saiu depois de um movimentado quarto de século. Maja Zehfuss, Antonio Vázquez-Arroyo e Dan Bulley e Bal Sokhi-Bulley oferecem meditações afiadas, ocasionalmente exasperadas, sobre a importância política da desconstrução e os limites dos diagnósticos de Derrida em Espectros de Marx, mas também identificam possíveis caminhos para uma política global inspirada. no trabalho de Derrida dos anos 1990.
\end{abstract}

Palavras-chave: Derrida, Jacques; desconstrução; política global; imigração; cidadania; ética; amizade.

Received on 9 July 2019, and approved for publication on 26 July 2019. 


\section{ERRATUM}

On article 'The Political Import of Deconstruction-Derrida's Limits?: A Forum on Jacques Derrida's Specters of Marx after 25 Years, Part I', with DOI number 10.1590/ s0102-8529.2019410300007, published on Contexto Internacional, 41(3): 621-642, on cover page in article thematic:

Where it reads:

ARTICLES

Should read:

FORUM: JACQUES DERRIDA'S SPECTERS OF MARX AFTER 25 YEARS 